\title{
Nutrient Foramina in the Upper and Lower Limb Long Bones: Morphometric Study in Bones of Southern Brazilian Adults
}

\author{
Forámenes Nutricios en los Huesos Largos de los Miembros Superiores e Inferiores: \\ Estudio Morfométrico en Huesos de Adultos del Sur de Brasil
}

Pereira, G. A. M.; Lopes, P. T. C.; Santos, A. M. P. V. \& Silveira, F. H. S.

PEREIRA, G. A. M.; LOPES, P. T. C.; SANTOS, A. M. P. V. \& SILVEIRA, F. H. S. Nutrient foramina in the upper and lower limb long bones: Morphometric study in bones of Southern Brazilian adults. Int. J. Morphol., 29(2):514-520, 2011.

SUMMARY: The major blood supply to long bones occurs through the nutrient arteries, which enter through the nutrient foramina. This supply is essential during the growing period, during the early phases of ossification, and in procedures such as bone grafts, tumor resections, traumas, congenital pseudoarthrosis, and in transplant techniques in orthopedics. The present study analyzed the location and the number of nutrient foramina in the diaphysis of 885 long bones of the upper and lower limbs of adults: 174 humeri, 157 radii, 146 ulnae, 152 femora, 142 tibiae and 114 fibulae. The location of the nutrient foramina is predominant on the anterior aspect of the upper limb long bones, and on the posterior aspect of the lower limb long bones. The majority of the bones studied had a single nutrient foramen, which may represent a single source of blood supply. The mean foraminal index for the upper limb bones was $55.2 \%$ for the humerus, $35.7 \%$ for the radius, and $37.9 \%$ for the ulna, and for the lower limb bones, $43.7 \%$ for the femur, $32.7 \%$ for the tibia and $46.1 \%$ for the fibula. This study recorded data related to the population of Southern Brazil, providing ethnic data to be used for comparison and that may help in surgical procedures and in the interpretation of radiological images.

KEY WORDS: Nutrient foramina; Long bones; Vascularization; Brazilian population.

\section{INTRODUCTION}

The nutrient foramina are cavities that conduct the nutrient arteries and the peripheral nerves. The major blood supply for long bones originates from the nutrient arteries, mainly during the growing period and during the early phases of ossification (Lewis, 1956; Brookes 1963; Sendemir \& Çimen, 1991; Gümüsburun et al., 1994; Kizilkanat et al., 2007). During childhood, long bones receive about $80 \%$ of the interosseous blood supply from the nutrient arteries, and in the case of their absence, the vascularization occurs through the periosteal vessels (Trueta, 1953). In bone grafts, the nutrient blood supply is crucial and it should be preserved in order to promote the fracture healing (Longia et al., 1980; Gümüsburun et al.). Moreover, the presence of preserved nutrient blood flow is essential for the survival of the osteocytes in cases of tumor resection, traumas, and congenital pseudoarthrosis (Sendemir \& Çimen; Gümüsburun et al.). Currently, the detailed study of blood supply to long bones is a determining factor for the success of new techniques for bone transplant and resection in orthopedics (Guo, 1981; Kirschner et al., 1998).
In transplant techniques, the use of statistical data on the nutrient foramina distribution in long bones makes it possible for the professional to select the osseous section levels of the receptor in order to place the graft without damaging the nutrient arteries, preserving, thus, the diaphyseal vascularization and the transplant consolidation (Wavreille et al., 2006). Studies on the vascularization of long bones of various populations were conducted analyzing the nutrient foramina morphometry (Sendemir \& Çimen; Nagel, 1993; Ciszek \& Glinkowski 2000; Lee et al., 2000; Dyankova, 2004; Chen et al., 2007; Kizilkanat et al.), the nutrient blood supply (Guo; Teot et al., 1984; Sheetz et al., 1995; Ebraheim et al., 1998; Kocabiyik et al., 2007; Thammaroj et al., 2007), the vascular anatomy in reconstructive surgeries (Hallock et al., 1993; Choi et al., 2001; Dyankova; Schiessel \& Zweymüller, 2004) and the microsurgically vascularized bone transplant (Guo; Bonnel,1981). Particularly on nutrient foramina, Shulmann (1959) considered that their location does not have a significant relationship with bone age, but that the nutrient 
artery development is primarily responsible for the nutrient channels form, rather than the bone development. In addition, Patake \& Mysorekar (1977) reported that the number of nutrient foramina does not seem to have a significant relationship with the bone length and the number of ossification centers.

The aim of this study was to record the location and number of nutrient foramina in long bones of the upper and lower limbs of adults in Southern Brazil.

\section{MATERIAL AND METHOD}

We analyzed 885 long bones from the Anatomy Laboratory of Universidade Luterana do Brasil, Canoas, Rio Grande do Sul state: 174 humeri, 157 radii, 146 ulnae, 152 femora, 142 tibiae and 114 fibulae. The laterality of the bones was the only known data, and right side and left side bones were identified; data about their age and gender were not available.

The localization, size and number of nutrient foramina were analyzed in each bone. Foramina smaller than a size 24 hipodermic needle were considered secondary

Table I. Location and number of nutrient foramina in the osseous surface in each of the upper limb bones. Humerus: AS- anterior surface, PS- posterior surface, PLS- posterolateral surface, AMSanteromedial surface; ulna: AS- anterior surface, ALS- anterolateral surface, AMS- anteromedial surface; radium: AS- anterior surface, ALS- anterolateral surface, PMS- posteromedial surface, AMSanteromedial surface.

\begin{tabular}{|c|c|c|}
\hline \multirow[t]{3}{*}{ Bone } & \multicolumn{2}{|c|}{ Number of foramina } \\
\hline & 1 & 2 \\
\hline & Number of bones( $\%)$ & Number of bones ( $\%$ ) \\
\hline Humerus & $n=174$ & $n=20$ \\
\hline AS & $8(4.6)$ & \\
\hline OS & $6(6)$ & $2(10)$ \\
\hline PLS & $4(2.3)$ & $1(5)$ \\
\hline MAS & $156(89.7)$ & $17(85)$ \\
\hline Ulna & $n=146$ & $\mathrm{n}=\mathbf{2}$ \\
\hline AS & $120(82.2)$ & $1(50)$ \\
\hline ALS & $17(11.6)$ & $1(50)$ \\
\hline MAS & $9(6.2)$ & \\
\hline Radium & $\mathrm{n}=\mathbf{1 5 7}$ & $\mathbf{n}=\mathbf{1}$ \\
\hline AS & $115(73.2)$ & \\
\hline ALS & $5(3.2)$ & \\
\hline PMS & $5(3.2)$ & \\
\hline MAS & $32(20.4)$ & $1(100)$ \\
\hline
\end{tabular}

foramina (Carroll, 1963; Lee et al.; Sendemir \& Çimen; Kizilkanat et al.), and these were not analyzed or reported in this study. Therefore, only the data on dominant foramina were considered and are referred to as nutrient foramina (NF). The NF distribution in the bone length was determined by calculating a foraminal index (FI), according to Hughes (1952), Shulman and Kizilkanat et al., using the formula: FI $=(\mathrm{DNF} / \mathrm{TL}) \times 100$, where DNF is the distance from the proximal end of the bone to the NF, and TL is the total bone length. Determination of the total length of individual bones was taken according to Forriol Campos et al. (1987) and Kizilkanat et al. A Vernier $500 \mathrm{~mm}$ paquimeter was used for all measurements.

The statistical data analysis was carried out using SPSS (Statistical Package for Social Sciences), version 15.0 for Windows. The descriptive statistical analysis was performed through frequency tables (single and crossed) and the calculation of the central tendency and variability measures (range, mean and standard deviation).

\section{RESULTS}

Most of the NF in the upper limb bones is located in the anterior aspect of the bones: $89.7 \%$ in the humerus, $82.2 \%$ in the ulna, and $73.2 \%$ in the radium (Table I). In the lower limb bones, most of the NF is found in the posterior aspect: $93.4 \%$ in the femur and $93.7 \%$ in the tibia, while in the fibula, $98.2 \%$ is located in the lateral aspect (Table II).

Table II. Location and number of nutrient foramina in the osseous surface in each of the lower limb bones. Femur: LA- linea aspera, LS- lateral surface, MS- medial surface; tibia: PS- posterior surface, MS- medial surface; fibula: LS- lateral surface, PS- posterior surface.

\begin{tabular}{lccc}
\hline Bone & \multicolumn{3}{c}{ Number of foramina } \\
\hline & 1 & 2 & 3 \\
\cline { 2 - 4 } Femur & $\begin{array}{c}\text { Number of } \\
\text { bones }(\%)\end{array}$ & $\begin{array}{c}\text { Number of } \\
\text { bones }(\%)\end{array}$ & $\begin{array}{c}\text { Number of } \\
\text { bones( } \%)\end{array}$ \\
\cline { 2 - 4 } LA & $\mathrm{n}=152$ & $\mathrm{n}=61$ & $\mathrm{n}=2$ \\
LS & $142(93.4)$ & $30(19.7)$ & $2(100)$ \\
MS & $10(6.6)$ & $30(19.7)$ & \\
Tibia & $\mathrm{n}=142$ & $1(0,7)$ & \\
PS & $133(93.7)$ & $\mathrm{n}=2$ & \\
MS & $9(6.3)$ & $2(100)$ & \\
Fibula & $\mathrm{n}=114$ & $\mathrm{n}=1$ & \\
LS & $112(98.2)$ & $1(100)$ & \\
PS & $2(1.8)$ & & \\
\hline
\end{tabular}


The number of NF observed in each bone is shown in Table III. Of all analyzed bones, $90.8 \%$ had a single nutrient foramen, and $8.9 \%$ had two NF. Only the femur had three NF. None of the bones had no NF in this study. The mean length for each bone was: $311.5 \mathrm{~mm}$ (humerus), $254.3 \mathrm{~mm}$ (ulna), $233.6 \mathrm{~mm}$ (radium), $444.1 \mathrm{~mm}$ (femur), $373.1 \mathrm{~mm}$ (tibia) and $356.6 \mathrm{~mm}$ (fibula). The humerus, the radium and the ulna showed the FI range, regardless of the surface, of: $32.1-68.8 \%, 22.8-57.5 \%$ and $27.4-52.5 \%$ respectively; the femur, the tibia and the fibula showed the following values, respectively: $26.1-68.9 \%, 26.2-$ $73.7 \%$ and $33.5-67.1 \%$ (Table IV). Also, results on the mean, standard deviation and range of FI were obtained an analysis of each bone, location and laterality (Table V).

Table III. Number of nutrient foramina observed in long bones.

\begin{tabular}{lccr}
\hline Bone & $\begin{array}{c}\text { Number of } \\
\text { foramina }\end{array}$ & $\begin{array}{c}\text { Number of } \\
\text { bones }\end{array}$ & $\%$ \\
\hline Humerus $(\mathrm{n}=154)$ & 1 & 154 & 88.5 \\
Ulna $(\mathrm{n}=146)$ & 2 & 20 & 11.5 \\
Radium $(\mathrm{n}=157)$ & 1 & 144 & 98.6 \\
& 2 & 2 & 1.4 \\
Femur $(\mathrm{n}=152)$ & 1 & 156 & 99.4 \\
& 1 & 1 & 0.6 \\
Tibia $(\mathrm{n}=142)$ & 2 & 97 & 63.8 \\
& 3 & 53 & 34.9 \\
Fibula $(\mathrm{n}=114)$ & 1 & 140 & 1.3 \\
& 2 & 2 & 98.6 \\
Total & 1 & 113 & 99.1 \\
& 2 & 1 & 0.9 \\
& 1 & 704 & 90.8 \\
& 2 & 2 & 8.9 \\
\hline
\end{tabular}

Table IV. Descriptive statistics for foraminal index - analysis by bone.

\begin{tabular}{|c|c|c|c|c|}
\hline FI & $\mathrm{n}$ & Range (min - max) & Mean & DP \\
\hline Bone & & $\%$ & & \\
\hline Humerus & 174 & $32.1-68.8$ & 55.2 & 7.0 \\
\hline Ulna & 146 & $27.4-52.5$ & 37.9 & 5.5 \\
\hline Radium & 157 & $22.8-57.5$ & 35.7 & 5.6 \\
\hline Femur & 152 & $26.1-68.9$ & 43.7 & 8.4 \\
\hline Tibia & 142 & $26.2-73.7$ & 32.7 & 4.6 \\
\hline Fibula & 114 & $33.5-67.1$ & 46.1 & 8.4 \\
\hline
\end{tabular}

\section{DISCUSSION}

The results, like those found by Forriol Campos et al., show that the NF of the upper limb bones are located nearer the elbow than the shoulder or wrist; in the lower limb bones, the NF is located closer to the hip on the femur, and at the junction of the proximal and medial bone on the tibia, with little variation (Fig. 1).

Humerus. The average length found in the humerus is similar to those obtained in previous studies (Carroll; GualdiRusso \& Galletti, 2004; Kizilkanat et al.), as well as the predominant location on the anteromedial surface (Forriol Campos et al.; Kizilkanat et al.). $100 \%$ of humeri have a single NF, different from the approximately $60 \%$ found by Carroll, Forriol Campos et al. and Kizilkanat et al. As for the percentage of bones with two NF, the results resemble those of Forriol Campos et al. and Kizilkanat et al. Carroll did not report the presence of two NF in these bones. The FI values are close to those reported by Carroll and Forriol Campos et al.

Radius.The radius average length is consistent with the data reported by Russo \& Gualdi-Russo \& Galletti and Kizilkanat et al. The predominance of NF was on the anterior surface (73.2\%), different from the $100 \%$ and the $29.8 \%$ reported by Forriol Campos et al. and Kizilkanat et al., respectively. Our results concerning the percentage of bones with a single NF $(100 \%)$ and two NF $(0.63 \%)$ are similar to previous studies (Forriol Campos et al.; Kizilkanat et al.). The FI found corroborates previous studies (Forriol Campos et al.; Kizilkanat et al.).

Ulna. The ulna average length is similar to the results reported by Guladi-Russo \& Galletti and Kizilkanat et al. $82.2 \%$ of the NF of the ulna is located on the anterior surface (Forriol Campos et al.), different from Kizilkanat et al. who reported the predominance in the anteromedial surface. All ulnae examined have at least one NF and $0.63 \%$ of the bones have two NF (Kizilkanat et al.). Forriol Campos et al. found values similar to the ones in this study for the presence of a single NF, but they reported $9 \%$ of the bones with two NF, a more expressive value than the $1.4 \%$ found in this analysis. The values of FI of 27.4 to $52.5 \%$ are close to those reported by Forriol Campos et al. and Kizilkanat et al.

Femur. The average length of the femur fits the results reported by Sendemir \& Çimen, Gümüsburun et al., Kizilkanat et al. and Collipal et al. (2007). The location in the linea aspera in $93.4 \%$ of the bones is similar to that reported by Forriol Campos et al., however, for Sendemir \& Çimen and Kizilkanat et al., in approximately $40 \%$ of the 
PEREIRA, G. A. M.; LOPES, P. T. C.; SANTOS, A. M. P. V. \& SILVEIRA, F. H. S. Nutrient foramina in the upper and lower limb long bones: Morphometric study in bones of Southern Brazilian adults. Int. J. Morphol., 29(2):514-520, 2011.

Table V. The mean, standard deviation (SD) and range of foraminal indices - for each bone, localization e side (right and left).

\begin{tabular}{|c|c|c|c|c|c|c|c|c|}
\hline \multirow[b]{2}{*}{ Bone } & \multirow[b]{2}{*}{ Location } & \multirow[b]{2}{*}{ Side } & \multicolumn{2}{|c|}{ I1 } & \multicolumn{2}{|c|}{$\mathbf{I 2}$} & \multicolumn{2}{|c|}{$\mathbf{I 3}$} \\
\hline & & & Range & Mean $(S D)$ & Range & $\operatorname{Mean}(S D)$ & Range & Mean $(S D)$ \\
\hline \multicolumn{9}{|c|}{ a) Humerus - right (R) and left (L) side } \\
\hline \multirow[t]{8}{*}{ Humerus ( $n=174)$} & \multirow[t]{2}{*}{ Anterior surface } & $\mathrm{R}$ & $26.1-50.2$ & $41.3(10.6)$ & $26.1-44.5$ & $35.3(13.0)$ & . & . \\
\hline & & $\mathrm{L}$ & $39.8-55.0$ & $46.9(7.6)$ & $38.4-45.0$ & $41.7(3.3)$ & . & . \\
\hline & \multirow[t]{2}{*}{ Posterior surface } & $\mathrm{R}$ & $35.7-54.4$ & $44.8(7.9)$ & $28.0-45.1$ & $36.5(12.1)$ & . & . \\
\hline & & $\mathrm{L}$ & $46.7-58.1$ & $52.4(8.1)$ & $40.1-40.1$ & $40.1(0.0)$ & . & . \\
\hline & \multirow[t]{2}{*}{ Postero-lateral surface } & $\mathrm{R}$ & $40.9-56.6$ & $48.3(7.9)$ & $33.9-33.9$ & $33.9(0.0)$ & . & . \\
\hline & & $\mathrm{L}$ & $60.4-60.4$ & $60.4(0.0)$ & $60.0-60.0$ & $60.0(0.0)$ & . & . \\
\hline & \multirow[t]{2}{*}{ Antero-medial surface } & $\mathrm{R}$ & $40.4-68.8$ & $56.1(6.1)$ & $37.2-49.8$ & $40.9(4.6)$ & . & . \\
\hline & & $\mathrm{L}$ & $42.4-67.6$ & $56.9(5.3)$ & $37.5-44.6$ & $40.9(2.9)$ & . & . \\
\hline \multicolumn{9}{|c|}{ b) Radium - right (R) and Left (L) side } \\
\hline \multirow[t]{8}{*}{ Radium $(n=157)$} & \multirow[t]{2}{*}{ Anterior surface } & $\mathrm{R}$ & $25.6-48.1$ & $34.5(4.6)$ & $31.1-31.1$ & $31.1(0.0)$ & . & . \\
\hline & & $\mathrm{L}$ & $22.8-46.3$ & $35.6(5.5)$ & . & . & . & . \\
\hline & \multirow[t]{2}{*}{ Antero-lateral surface } & $\mathrm{R}$ & $30.8-30.9$ & $30.8(0.1)$ & . & . & . & . \\
\hline & & $\mathrm{L}$ & $28.2-42.5$ & $34.2(7.4)$ & . & . & . & . \\
\hline & \multirow[t]{2}{*}{ Postero-medial surface } & $\mathrm{R}$ & $35.4-36.4$ & $35.9(0.7)$ & . & . & . & . \\
\hline & & $\mathrm{L}$ & $38.3-40.8$ & $39.7(1.3)$ & . & . & . & . \\
\hline & \multirow[t]{2}{*}{ Antero-medial surface } & $\mathrm{R}$ & $29.1-44.1$ & $37.2(4.8)$ & . & . & . & . \\
\hline & & $\mathrm{L}$ & $25.0-51.2$ & $37.1(7.4)$ & . & . & . & . \\
\hline \multicolumn{9}{|c|}{ c) Ulna - right (R) and left (L) side } \\
\hline \multirow[t]{6}{*}{$\operatorname{Ulna}(n=146)$} & \multirow[t]{2}{*}{ Anterior surface } & $\mathrm{R}$ & $27.9-47.5$ & $36.9(5.0)$ & . & . & . & . \\
\hline & & $\mathrm{L}$ & $27.4-51.7$ & $37.6(5.1)$ & $36.5-42.2$ & $39.4(4.0)$ & . & . \\
\hline & \multirow[t]{2}{*}{ Antero-lateral surface } & $\mathrm{R}$ & $38.1-48.5$ & $42.7(3.9)$ & . & . & . & . \\
\hline & & $\mathrm{L}$ & $29.1-52.5$ & $43.4(8.4)$ & . & . & . & . \\
\hline & \multirow[t]{2}{*}{ Antero-medi al surface } & $\mathrm{R}$ & $32.0-45.9$ & $37.7(5.0)$ & . & . & . & . \\
\hline & & $\mathrm{L}$ & $32.1-39.2$ & $35.6(5.1)$ & . & . & . & . \\
\hline d) Femur - right ( & ) and left ( $L$ ) side & & & & & & & \\
\hline Femur $(n=152)$ & Linea aspera & $\mathrm{R}$ & $27.1-68.9$ & $40.6(8.7)$ & $44.9-66.8$ & $58.0(5.9)$ & . & . \\
\hline & & $\mathrm{L}$ & $26.1-64.0$ & $38.1(7.3)$ & $31.1-64.7$ & $55.2(7.1)$ & $40.8-63.0$ & $51.9(15.7)$ \\
\hline & Medial surface & $\mathrm{R}$ & $28.2-28.2$ & $28.2(0.0)$ & . & . & . &. \\
\hline & & $\mathrm{L}$ & . & . & . & . & . & . \\
\hline & Lateral surface & $\mathrm{R}$ & $29.5-56.4$ & $47.4(15,)$. & $53.1-53.1$ & $53.1(0.0)$ & . & . \\
\hline & & $\mathrm{L}$ & $33.7-59.0$ & $52.6(8.8)$ & . & & . & . \\
\hline e) Tibia - right ( $R$ & and left $(L)$ side & & & & & & & \\
\hline Tibia $(n=142)$ & Posterior surface & $\mathrm{R}$ & $26.2-73.7$ & $32.9(6.0)$ & $42.0-42.8$ & $42.4(0.5)$ & . & . \\
\hline & & $\mathrm{L}$ & $26.4-42.7$ & $32.3(2.8)$ & . & . & . & . \\
\hline & Medial surface & $\mathrm{R}$ & $29.5-40.1$ & $32.3(4.1)$ & . & . & . & . \\
\hline & & $\mathrm{L}$ & $30.7-35.6$ & $33.0(2.5)$ & . & . & . & . \\
\hline f) Fibula - right a & Id left $(L)$ side & & & & & & & \\
\hline Fibula $(n=114)$ & Lateral surface & $\mathrm{R}$ & $33.5-67.1$ & $45.6(8.9)$ & . & . & . & . \\
\hline & & $\mathrm{L}$ & $33.7-63.4$ & $46.5(7.8)$ & $63.7-63.7$ & $63.7(0.0)$ & . & . \\
\hline & Posterior surface & $\mathrm{R}$ & . & . & . & . & . & . \\
\hline & & $\mathrm{L}$ & $34.2-54.6$ & $44.4(14.4)$ & & & & . \\
\hline
\end{tabular}

bones the NF are located in this region. Although $97.4 \%$ of the bones examined have only one NF, Forriol Campos et al., Gümüsburun et al. and Kizilkanat et al. reported approximately $30 \%$ with this feature. The observation that about $40 \%$ of the bones have two NF is similar to that reported by Mysorekar (1967), Sendemir \& Çimen and 
Gümüsburun et al. and differs from the values reported by Forriol Campos et al. (75\%) and Kizilkanat et al. (60\%). Three NF were found only in $1.28 \%$ of the femora studied, in disagreement with Forriol Campos et al. and Gümüsburun et al., who reported approximately $10 \%$. Although no femur showed more than three NF, previous studies have reported femora with eight to nine NF (Sendemir \& Çimen) and with four to six NF (Gümüsburun et al.). In agreement with Sendemir \& Çimen and Kizilkanat et al., none of the bones studied showed an absence of NF, although Gümüsburun $e t$ al. reported $1.9 \%$. The result of the FI is similar to those reported by Forriol Campos et al., Gümüsburun et al. and Kizilkanat et al.

Tibia. The average length of the tibia is similar to previous results (Sendemir \& Çimen; Gümüsburun et al.; Kizilkanat et al.; Collipal et al., 93.7\%) of NF is on the posterior surface (Forriol Campos et al.; Gümüsburun et al.; Kizilkanat et al.. 100\%) of the tibiae have one NF (Forriol Campos et al.; Gümüsburun et al.; Kizilkanat et al.). Only 1.4\% of the bones studied have two NF (Kizilkanat et al.), different from the $7 \%$ and $11.3 \%$ found by Forriol Campos et al. and Gümüsburun et al., respectively. The latter showed the presence of $2.8 \%$ of the bones with three NF. None of the tibia showed no NF. The values of FI are close to those reported by Gümüsburun $e t a l$. and Kizilkanat $e t$ al. and far from those by Forriol Campos et al. (30 - 40.6\%).
Fibula. Gümüsburun et al., Kizilkanat et al. and Collipal et al. found values similar to the ones in this study regarding the average length of the fibula. Predominance of NF occurred on the lateral surface, in disagreement with the results of Forriol Campos et al., Gümüsburun et al., Lee et $a l$. and Kizilkanat et al., who reported that the posterior surface was predominant. All fibulae analyzed have at least one NF (Guo; Forriol Campos et al.; Gümüsburun et al.; Lee et al.; Kizilkanat et al.), while $0.87 \%$ has two NF. Guo, Kizilkanat et al. and Gümüsburun et al. found two NF in the fibulae, $3.3 \%, 5.4 \%$ and $11.6 \%$, respectively. No bones showed an absence of NF, which differs from Gümüsburun et al. and Kizilkanat et al., who recorded 3.3\% and 1.3\%, respectively. Data for the FI are similar to previous studies (Forriol Campos et al.; Gümüsburun et al.; Lee et al.), although Kizilkanat et al. found a FI between 25.8 and 82.6\%. Forriol Campos et al. and Gümüsburun et al. reported the middle third as the location of NF, and Guo, the upper third of the bones.

\section{CONCLUSIONS}

The results on the nutrient foramina incidence and distribution in long bones are consistent with most studies. The analysis on the nutrient foramina distribution indicates

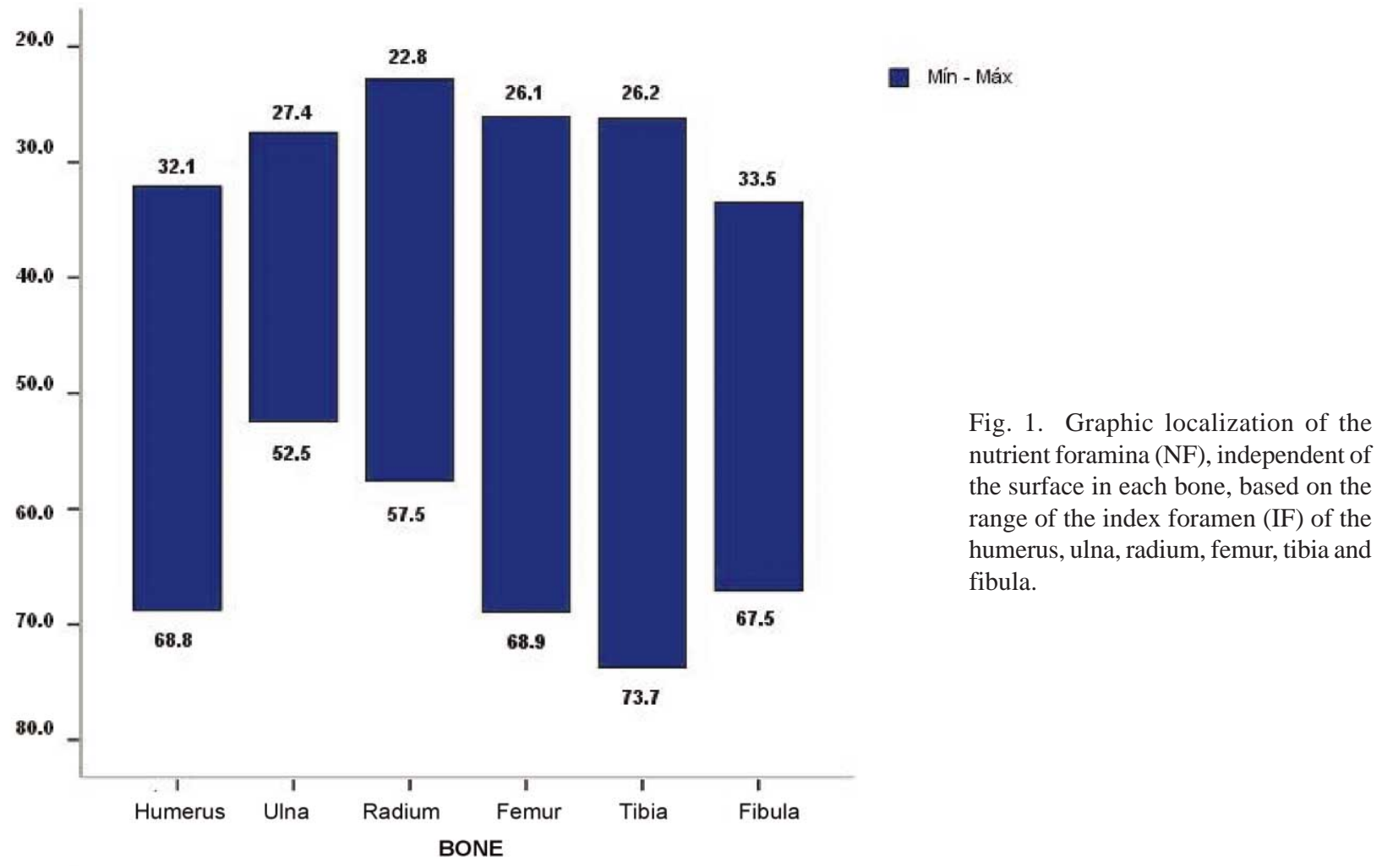


that they are located predominantly on the anterior surface in long bones of the lower limbs, which corroborates with previous results on the localization of NF in the flexor surface of those bones. Of all parameters examined in this study on subjects from Southern Brazil, the FI was the one which came closest in comparison with previous studies on the Turkish and Spanish populations. The results on the localization of NF in the fibula disagreed with the results of studies on the Turkish, Japanese and Spanish populations. Most long bones analyzed in this study have only one NF and may represent the only source of blood supply. Thus, the areas of NF distribution must be, whenever possible, avoided during surgery. This study recorded data related to the population of Southern Brazil, providing ethnic data to be used for comparison and that may help in surgical procedures and in the interpretation of radiological images.

PEREIRA, G. A. M.; LOPES, P. T. C.; SANTOS, A. M. P. V. \& SILVEIRA, F. H. S. Forámenes nutricios de los miembros superiores e inferiores en huesos largos: Estudio morfométrico en huesos de adultos del sur de Brasil. Int. J. Morphol., 29(2):514-520, 2011.

RESUMEN: El importante aporte de sangre para los huesos largos se produce a través de las arterias nutricias, que penetran por los forámenes nutricios. Este suministro es esencial durante el período de crecimiento, las primeras fases de osificación y en los procedimientos como injertos óseos, resecciones tumorales, traumas, pseudoartrosis congénita y en las técnicas de trasplante en ortopedia. El estudio determina la ubicación y el número de forámenes nutricios en las diáfisis de 885 huesos largos de los miembros superiores e inferiores pertenecientes a individuos adultos. Fueron estudiados 174 húmeros, 157 radios, 146 ulnas, 152 fémures, 142 tibias y 114 fíbulas. La ubicación de los forámenes nutricios era predominante en la parte anterior de la diáfisis de los huesos largos del miembro superior y en la parte posterior de los huesos largos del miembro inferior. La mayoría de los huesos estudiados tenía un solo foramen nutricio, representando una sola fuente de suministro de sangre. El índice medio foraminal en los huesos del miembro superior fue de 55,2\% para el húmero, 35,7\% para el radio, y 37,9\% para el ulna; en los huesos del miembro inferior fue 43,7\% para el fémur, 32,7\% para la tibia y 46,1\% para la fíbula. Este estudio registró datos relativos a la población del Sur de Brasil, proporcionando antecedentes étnicos que además puedan servir de ayuda en los procedimientos quirúrgicos y en la interpretación de imágenes radiológicas.

PALABRAS CLAVE: Foramen nutricio; Hueso largo; Vascularización; Población brasileña.

\section{REFERENCES}

Bonnel, F.; Desire, M.; Gomis, R.; Allieu, Y. \& Rabischong, P. Arterial vascularization of the fibula microsurgical transplant techniques. Anat. Clin., 3:13-22, 1981.

Brookes, M. Blood supply of long bones. Br. Med. J., 2:1064$5,1963$.

Carroll, S. E. A study of the nutrient foramina of the humeral diaphisis. J. Bone Joint Surg. Br., 45-B:176-81, 1963.

Chen, B.; Pei, G. X.; Jin, D.; Wei, K. H.; Qin, Y. \& Liu, Q. $\mathrm{S}$. Distribution and property of nerve fibers in human long bones tissue. Chin. J. Traumatol., 10:3-9, 2007.

Choi, S. W.; Kim, H. J.; Koh, K. S.; Chung, I. H. \& Cha, I. H. Topographical anatomy of the fibula and peroneal artery in Koreans. Int. J. Oral Maxillofac. Surg., 30:329-32, 2001.

Ciszek, B. \& Glinkowski, W. Nutrient foramina in the diaphyses of long bones. Ortop. Traumatol. Rehabil., 2:97-9, 2000.

Collipal, E.; Vargas, R.; Parra, X.; Silva, E. \& Del Sol, M. Diaphyseal nutrient foramina in the femur, tibia and fibula bones. Int. J. Morphol., 25:305-8, 2007.
Dyankova, S. Vascular anatomy of the radius and ulna diaphyses in their reconstructive surgery. Acta Chir. Plast., 46:105-9, 2004.

Ebraheim, N. A.; Lu, J.; Hao, Y. \& Biyani, A. Yeasting RA Anterior tibial artery and its actual projection on the lateral aspect of the tibia: a cadaveric study. Surg. Radiol. Anat., 20:259-62, 1998.

Forriol Campos, F.; Pellico, L. G.; Alias, M. G. \& FernandezValencia, R. A study of the nutrient foramina in human long bones. Surg. Radiol. Anat., 9:251-5, 1987.

Gualdi-Russo, E. \& Galletti, L. Human activity patterns and skeletal metric indicators in the upper limb. Coll. Antropol., 28:131-43, 2004.

Gümüsburun, E.; Yucel, F.; Ozkan, Y. \& Akgun, Z. A study of the nutrient foramina of lower limb long bones. Surg. Radiol. Anat., 16:409-12, 1994.

Guo, F. Observations of the blood supply to the fibula. Arch. Orthop. Traumat. Surg., 98:147-51, 1981.

Hallock, G. G.; Anous, M. M. \& Sheridan, B. C. The surgical 
anatomy of the principal nutrient vessel of the tibia. Plast. Reconstr. Surg., 92:49-54, 1993.

Hughes, H. The factors determining the direction of the canal for the nutrient artery in the long bones of mammals and birds. Acta Anat., 15:261-80, 1952.

Kirschner, M. H.; Menck, J.; Hennerbichler, A.; Gaber, O. \& Hofmann, G. O. Importance of arterial blood supply to the femur and tibia transplantation of vascularized femoral diaphiseal and knee joints. World J. Surg., 22:845-52, 1998.

Kizilkanat, E.; Boyan, N.; Ozsahin, E. T.; Soames, R. \& Oguz, O. Location, number and clinical significance of nutrient foramina in human long bones. Ann. Anat., 189:87-95, 2007.

Kocabiyik, N.; Yalçin, B. \& Ozan, H. Variations of the nutrient artery of the fibula. Clin. Anat., 20:440-3, 2007.

Lee, J. H.; Ehara, S.; Tamakawa, Y. \& Horiguchi, M. Nutrient canal of the fibula. Skeletal Radiol., 29:22-6, 2000 .

Lewis, O. J. The blood supply of developing long bones with special reference to the metaphyses. J. Bone Joint Surg., 38B:928-33, 1956.

Longia, G. S.; Ajmani, M. L.; Saxena, S. K. \& Thomas, R. J. Study of diaphyseal nutrient foramina in human long bones. Acta Anat., 107:399-406, 1980.

Mysorekar, V. R. Diaphysal nutrient foramina in human long bones. J. Anat., 101:813-22, 1967.

Nagel, A. The clinical significance of the nutrient artery. Orthop. Rev., 22:557-61, 1993.

Patake, S. M. \& Mysorekar, V. R. Diaphyseal nutrient foramina in human metacarpals and metatarsals. $J$. Anat., 124:299-304, 1977.

Schiessel, A. \& Zweymüller, K. The nutrient artery canal of the femur: a radiological study in patients with primary total hip replacement. Skeletal Radiol., 33:1429, 2004.

Sendemir, E. \& Çimen, A. Nutrient foramina in the shafts of lower limb long bones: situation and number. Surg. Radiol. Anat., 13:105-8, 1991.
Sheetz, K. K.; Bishop, A. T. \& Berger, R. A. The arterial blood supply of the distal radius and ulna and its potential use in vascularized pedicled bone grafts. J. Hand. Surg. 20:902-14, 1995.

Shulman, S. S. Observations of the nutrient foramina of the human radius and ulna. Anat. Rec., 134:685-97, 1959.

Thammaroj, T.; Jianmongkol, S. \& Kamanarong, K. Vascular anatomy of the proximal fibula from embalmed cadaveric dissection. J. Med. Assoc. Thai., 90:942-6, 2007.

Teot, L.; Gilbert, A.; Amichot, G.; Bernière, J.; Pous, J.G. \& Carlioz, H. Epiphyseal vascularization during growth: the upper limb. Ann. Chir. Main., 3:237-44, 1984.

Trueta, J. Blood supply and the rate of healing of tibial fractures. Clin. Orthop. Rel. Res., 105:11-26, 1953.

Wavreille, G.; Dos Remédios, C.; Chantelot, C.; Limousin, M. \& Fontaine, C. Anatomic bases of vascularized elbow joint harvesting to achieve vascularized allograft. Surg. Radiol. Anat., 28:498-510, 2006.

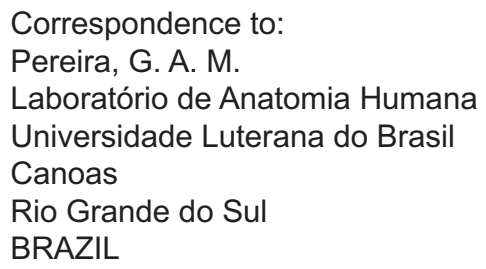

Email:gabrielaulbra@gmail.com

Received: $13-11-2010$

Accepted: 27-02-2011 